\title{
From the Archaeological Turn to 'Codicologie Structurale': The Concept of Codicology and the Material Description of Hebrew Manuscripts
}

\begin{abstract}
This article explores the concept of codicology adopted by generations of scholars who have studied mediaeval manuscripts since the mid-20 ${ }^{\text {th }}$ century. Several different methodological approaches are outlined - from the 'archaeological turn' to comparative and structural codicology, including quantitative and historical approaches. The study of Hebrew manuscripts is seen in the context of the development of these methodological approaches. Different views on how a Hebrew manuscript should be described and what a catalogue of Hebrew manuscripts should look like are outlined, including the approach that is currently being followed in a project involving the creation of new catalogues of Hebrew manuscripts kept at the Bibliothèque nationale de France launched in 2007. The article also analyses two specific examples of Hebrew manuscripts where all these questions are relevant.
\end{abstract}

\section{The archaeological turn}

In 1950, François Masai published an article in Scriptorium that can be regarded as having founded a new perspective for studying mediaeval manuscripts and the related disciplines of palaeography and codicology. In his article, Masai asserts:

Il y faut soigneusement distinguer les disciplines historiques et les disciplines archéologiques. C'est parmi les premières qu'il convient de ranger, avons-nous vu, la bibliologie, la paléographie proprement dite et l'histoire de l'enluminure. Par contre la codicologie constitue une branche de l'archéologie. [...] Ce n'est pas la paléographie qu'il faut coordonner à la diplomatique, comme on le fait couramment, mais la codicologie. Tandis que la diplo-

This research is part of a collaborative project entitled 'Legado de Sefarad II. La producción material e intelectual del judaísmo sefardí bajomedieval', which is based at the ILC-CSIC in Madrid and supported by the Plan Nacional de I+D+i (FFI2015-63700-P).

DOI 10.1515/9783110546422-002, (cc)BY-NC-ND (02017 J. del Barco, published by De Gruyter. This work is licensed under the Creative Commons Attribution-NonCommercial-NoDerivs 3.0 License. 
matique étudie concrètement, expertise en un mot, les documents d'archives, les «papiers» des institutions et des particuliers, la codicologie expertise les livres manuscrits. Elles ont en commun d'être toutes deux des disciplines archéologiques, mais chacune possède son champ de fouille bien délimité [...]. ${ }^{1}$

The novelty of Masai's proposal is twofold. On the one hand, he advocates codicology's independence from palaeography, two disciplines that differ not only in their aims, but also in the methods they employ. This breaks with the tradition of palaeography encompassing not only the study of scripts, but also that of the writing surface and everything else that is analysed in order to date a manuscript. ${ }^{2}$ On the other hand, with respect to methodology, Masai situates codicology - along with diplomatics - within the specific sphere of 'archaeological disciplines'. He denies codicology the status of a historical discipline and, therefore, the capacity for engaging in interpretation of data and its contextualisation within the history of the book in particular and cultural history in general. ${ }^{3}$ This clear positioning of codicology as an archaeological discipline, subject to a working method based on the demarcation and description of each stage in a manuscript's production, similar to the stratigraphic description of archaeological excavations, conditioned the evolution of codicology over subsequent decades.

Moreover, by placing codicology between archaeological disciplines, Masai challenged the link between the study of manuscripts and literary history formulated by $19^{\text {th }}$-century scholars (most of whom were German) and raised the question about the precise nature of codicology and its place among the historical and philological disciplines. Contrary to Masai's concept of codicology as an archaeological discipline, the study of manuscripts had been generally linked to literary history and philology up till the early $1930 s .{ }^{4}$ It was in the course that

1 Masai 1950, 292.

2 With the exception of the German tradition, in which the term 'Handschriftenkunde' was used for the material study of manuscripts and 'Paläographie' for the study of writing following the publication of Friedrich Adolf Ebert's Zur Handschriftenkunde (1825) and as a result of the influence of Ludwig Traube's 'Munich school'. See below.

3 See Muzerelle 1991, 349: 'Masai dénie catégoriquement à la codicologie le droit de se livrer à la moindre interprétation des faits qu'elle observe et l'instance avec laquelle il lui refuse la qualité de discipline historique.'

4 See Olszowy-Schlanger 2012, 260. Moritz Steinschneider, considered the father of Hebrew bibliography, declared in 1897: 'Der Inhalt dieser Vorlesungen [über die Kunde hebräischer Handschriften, deren Sammlungen und Verzeichnisse] könnte als ein Bestandteil der Einleitung in die jüdische Litteratur angesehen werden', thereby establishing a direct relationship between the study of manuscripts and the study of Hebrew literature, Steinschneider 1897, 1. 
Charles Samaran offered at the École Pratique des Hautes Études in 1934/35 that he advocated the independence of manuscript science from philology by defining the term 'codicography', which he understood to be parallel to 'bibliography', but with reference to the manuscript book. However, Samaran's proposal was not as successful as he had hoped, and the term that eventually gained acceptance - 'codicology' - was coined by Alphonse Dain shortly thereafter to refer to the history of manuscripts and their collections, research on the location of manuscripts, their use, etc. In other words, Dain's term does not include the study of material aspects of codices, which he assumed belonged to palaeography. ${ }^{5}$ At this point, the term proposed by Dain to encompass the discipline concerned with the history of manuscripts and their collections was taken up by Masai to refer to manuscript science, which was thought to be independent of palaeography and whose methods were subsumed under those of the archaeological sciences.

Léon M. J. Delaissé, who was one of Masai's disciples and a follower of his proposal to understand codicology as an 'archaeology of the book', preferred to use the latter term instead of codicology to refer to the material examination of manuscripts. He understood it as 'l'examen matériel complet du livre et l'interprétation des faits observés, par rapport au contenu'. ${ }^{6}$ Far from falling into disuse, the archaeological method in codicology gained renewed momentum at the end of the 1970s thanks to Léon Gilissen, considered by many to be the founding father of a genuine archaeology of the book. In the first of the two essays that make up his Prolegomènes à la codicologie, ${ }^{7}$ Gilissen takes up the study of what, archaeologically speaking, might be called a 'site' of twenty parchment manuscripts, and analyses the data on the composition of quires in detail, coming to the conclusion that a quire is not an accidental grouping of bifolia cut separately, but the result of folding an entire skin according to precise rules; this creates a complete quire. His method in this and other questions regarding the material production of mediaeval manuscripts has paved the way for a much more detailed understanding of the conception and techniques of mediaeval book production, including not only the preparation of materials and space for copying the text and images, but also their execution.

5 As has been said already, this was commonly accepted until Masai's publications, except for the case of the German school (see above note 2). On the history of codicology up to the time of François Masai, see Gruys 1976, 27-33.

6 In other words, as an auxiliary discipline of either the historian or the philologist. See Delaissé 1956, 2.

7 Gilissen 1977. 


\section{Codicology 'lato sensu' and codicology 'stricto sensu'}

Since the beginning of the 1970 s, various ${ }^{8}$ other voices had already been claiming that 'codicology' should not just be concerned with the 'archaeology of the book', but also with its history, usage and reception as a cultural and textual object. Two ways of understanding codicology as a discipline - two schools, one might say arose as a result.

On the one hand, there is codicology 'stricto sensu', which adheres to the archaeological objectives outlined by Masai and his followers without venturing into questions beyond a material analysis and description of the object. On the other hand, we have codicology 'lato sensu', which approaches the manuscript as a historical, cultural and textual object and thus requires a degree of study that does not just focus on the material description of the object. ${ }^{9}$ Some scholars - mostly historians - understand that this codicology 'lato sensu' should be extended to include the production, use, transmission and meaning of a book in its historical and cultural context, whereas others - mostly philologists concerned with codicology - tend to broaden the field to include textual and literary criticism and the transmission of texts. ${ }^{10}$

Thus, the meaning of the term 'codicology' varies from one author to another, depending on the dialectic discussion about codicology 'stricto sensu' and 'lato sensu'. Marilena Maniaci, for instance, states in her Archeologia del manoscritto which aspects of the history of manuscript books she will and will not be dealing with. Although she does not define precisely how she uses the term 'codicology', she does explain that 'I materiali costitutivi, le tecniche di fabbricazione, le modalità esecutive e la presentazione del libro manoscritto fanno quindi parte

8 For instance, the late Charles Samaran, Ezio Ornato, and Maria Luisa Agati, among others. See below.

9 See Gruys/Gumbert 1976, 11; Dérolez 1973. See also the more recent work by Muzerelle 1991, 350 and Agati 2009, 35.

10 In 1976, Samaran had also adopted the distinction between codicology 'au sens étroit' and codicology 'au sens large', understanding the former to be the artisanal technique of the book. As for the second sense, it is interesting how Samaran relates it to the history of the transmission of texts and to textual criticism by defining it like this: 'c'est celle qui ajoute à l'étude du livre manuscrit celle du livre imprimé, sa suite naturelle, et qui, outre les manuscrits considérés en eux-mêmes, ne néglige pas les textes que ces manuscrits représentent dans leur infinie complexité, manuscrits d'auteurs ou copies, contemporaines ou tardives, variantes, éditions successives, etc.'; see Gruys/Gumbert 1976, vol. 1, 9. 
del territorio «naturale» della codicologia' ${ }^{11}$ In other words, it comprises all those elements that are related to the material production of a manuscript and its status as an object. Thus, in the connotation she gives it, which is similar to Masai's, Delaissé's and Gilissen's, the term does not include anything having to do with the history of the text and images except those elements that are directly related to the material dimension of the manuscript, particularly the physical interaction between the writing and the decoration on its pages - so it has nothing to do with textual criticism, with whether the book belonged to a private collection or a large library, with an overall analysis of the production or use of the book, or with issues involved in the conservation and restoration of the manuscript. Because of her conception of the archaeological nature of codicology, Maniaci's study is limited to the material aspects of book production and therefore ignores not only what is the proper subject of the philologist - the history of the text and textual criticism - and the restorer, but issues that concern book historians, such as the study of manuscripts as part of book collections, from their genesis and throughout their transformations, or the socio-economic and cultural aspects of a manuscript's production, use and transmission.

In contrast, Maria Luisa Agati, in her introduction to Il libro manoscritto da Oriente a Occidente, asserts that her understanding of the term is broader. According to her:

[...] la Codicologia, o scienza del libro manoscritto, è 'integrale’': comprende una prima parte limitata, appunto, allo studio materiale del libro-oggetto/reperto (archeologia), per conoscerlo a fondo e comprenderlo, che [...] è importante per chi studia la storia del libro. Poi, però, guarda più lontano: non ignora l'interattività con le discipline filologiche e paleografiche, le quali costituiscono solo un approcio diferente alla stessa realtà-codex; e neppureelude aspetti come la trascrizione, la leggibilità, la decorazione, la storia delle biblioteche e, sopratutto, la conservazione e catalogazione. ${ }^{12}$

For Agati, then, in addition to an archaeological analysis of the manuscript, codicology includes some of the issues that Maniaci excluded from her manual, Archeologia del manoscritto, such as the study of palaeographical features, decoration and the history of libraries.

Because of this twofold understanding of the term 'codicology', its use generally has to be explained in all its nuances. ${ }^{13}$ Whereas the term 'archaeology of the

11 Maniaci 2002, 10.

12 Agati 2009, 22.

13 In a review of Gruys and Gumbert's Codicologica, vol. 1 (1976), from 1978, Emmanuel Poulle formulated his doubts about the precise lines of demarcation between the two approaches and 
book' enjoys a degree of success and refers unambiguously to codicology 'stricto sensu', the term 'codicology', whose etymology refers to the study of mediaeval codices, continues to be used with different - and sometimes contradictory connotations. Some understand it as a synonym of 'archaeology of the book', while others understand it as codicology 'lato sensu'. Even among the latter, the issues to be investigated by codicology vary - cultural and social issues for the historian, for example, and textual criticism and the history of the transmission of texts for the philologist. This creates grey areas and even some overlapping, such that explicit clarification of what is meant is usually called for when the term is used. ${ }^{14}$

\section{The impact of quantitative codicology}

In their foundational book on quantitative codicology, ${ }^{15}$ Carla Bozzolo and Ezio Ornato complain that the historical study of manuscripts was usually understood as a secondary or elitist pursuit until the late 1970s: either as a tool for accessing intellectual history or, conversely, as a means for studying a small number of art objects - illuminated manuscripts - that are worthy of interest only because they are different from the thousands of more ordinary manuscripts. They advocate the study of just this multitude of ordinary manuscripts, which they call 'foule anonyme de manuscrits', ${ }^{16}$ applying the archaeological method, but with the objective of answering questions ${ }^{17}$ that go beyond a particular, isolated manuscript by means of quantitative analysis.

came to the conclusion that the codicologist would have to draw the boundaries of his or her own discipline: 'Ces distinctions [entre codicologie "stricto sensu" et "lato sensu"] sont sans doute fondées, mais, s'agissant de domaines voisins de recherche dans lesquels, le plus souvent, les mêmes savants se trouveront impliqués, il est probablement plus facile d'en faire état en théorie que dans la pratique. En fait, ce sont les codicologues qui arbitreront eux-mêmes ces débats de principes: le contenu de la codicologie sera, en définitive, ce qu'ils y mettront', Poulle 1978, 150. 14 Maniaci also echoes this ambiguity in the term according to the researcher's approach to the mediaeval codex: 'Va riconosciuto che la valenza scientifica e concreta del termine «codicologia» comporta non poche zone d'ombra, in quanto è ancor oggi oggetto di interpretazioni esplicite o implicite significativamente divergenti', Maniaci 2002, 9.

15 Bozzolo/Ornato 1980.

16 Bozzolo/Ornato 1980, 9.

17 Bozzolo/Ornato 1980, 9: ‘Combien de livres a-t-on écrit à telle ou telle époque au Moyen Age? A quel prix? Par quelles techniques? Ce sont là les principales questions que nous nous sommes posées en essayant de replacer le manuscrit dans son environnement matériel.' 
Inasmuch as codicology 'lato sensu' is understood by historians as a discipline that deals simultaneously with all aspects of the mediaeval book, from the nature of the materials used and the phases of material production to the modes of conservation, reading and dissemination, for Bozzolo and Ornato it is something very similar to the history of the book, which begins with a material - archaeological - analysis, but also assumes the prerogative to explore and respond to questions that were formerly seen as being the exclusive concern of historians and philologists. ${ }^{18}$

When explaining the title of the book La face cachée du livre médiéval, a collection of articles by Ornato and his colleagues and friends, the former defines the two 'faces' of a manuscript, which must be dealt with by codicologists and book historians:

[...] à l'égal de la lune, le livre a deux faces. L'une, éclairée, placée en quelque sorte «au beau milieu du ciel», correspond à ce qui est habituellement regardé ou lu: le texte, l'écriture, la décoration, les illustrations, la reliure; l'autre, obscure, est reléguée à l'arrière-plan et n'est pas consciemment perçue - à la limite parce qu'on voulait qu'il en fût ainsi - ni par le lecteur ni, ce qui est plus regrettable, par le spécialiste du livre médiéval. Dans cette catégorie, il faut ranger d'une part des éléments internes au livre, tels que la « charpente du texte » qui soutient la lecture, les pratiques artisanales ou graphiques peu apparentes, les défauts, les négligences ou les incohérences de tout genre [...] De l'autre, des éléments externes, à savoir les aspects culturels, économiques, sociologiques et technologiques qui, en interagissant sans cesse avec la fonction fondamentale du livre - assurer bien et vite la transmission de la culture - conditionnent la structure, la présentation et, finalement, l'évolution de ce dernier. ${ }^{19}$

In this quote, Ornato articulates a fundamental idea in his understanding of codicology, namely that the study of the 'inner' part of the manuscript - the material and technological aspects of book production - cannot be separated from the 'exterior' part - the socio-cultural and economic aspects - because the latter has a decisive influence on the design of the former.

The obligation to take up the exterior study of manuscripts leads him to defend a quantitative method. This method denies the importance of any individual manuscript and instead seeks quantifiable elements from among 'la foule anonyme de manuscrits' that can be subject to comparison and examination

18 In the words of Ornato, a codicology 'qui soit tout le contraire d'une "science auxiliaire", notion de plus en plus souvent condamné mais encore bien vivante dans les mœurs, les institutions et même les esprits'. See Ornato/Bozzolo 1982, 267. Cited in Armando Petrucci, 'Prefazione', in Ornato 1997, vii.

19 Ornato 1997, xiii. 
and can therefore provide an idea of the economic and cultural determinants of manuscript production at a particular time and place, or conversely, throughout a longer period of time. As a result, Ornato and his school of followers consider codicology to be an independent and autonomous discipline within the historical sciences, at the same level as other specialisations and not subservient to any of them.

At this point, it is obvious that, in spite of the fact that Ornato also understands codicology as something more than the archaeological study of manuscripts, his methodological approach is radically different from what other authors have understood as codicology 'lato sensu': for Ornato, it is not a matter of carrying out an integral study of a particular codex (medium, palaeography, illumination, history, function), but of formulating questions about the production of mediaeval books in general (selection of materials, fabrication of quires, number of volumes, prices, work invested, circulation) based on a statistical analysis of quantitative data drawn from a certain 'population' of manuscripts, selected according to chronological criteria, area of production, type of book, etc.

The quantitative trend begun by Ornato and his school for the study of Latin and Western manuscripts had a strong impact on Hebrew codicology, which was only just being established at the time. When Malachi Beit-Arié published Hebrew Codicology in $1977,{ }^{20}$ he had already researched the techniques used in the production of dated Hebrew codices, which were being catalogued by the members of the Comité de paléographie hébraïque, ${ }^{21}$ to which he belonged. In order to facilitate the study of mediaeval Hebrew book-production techniques in general as well as comparatively, given the wide range of geographic areas where Hebrew manuscripts were copied in the Middle Ages, Beit-Arié undertook the creation of a database (a novel endeavour for the time) containing the most-relevant data on the material production of each manuscript, which has been shown to be a powerful analytical tool. ${ }^{22}$ Although Hebrew Codicology, a pioneering work, focused primarily on questions related to technical aspects of the material production of books, ${ }^{23}$ Beit-Arié soon foresaw the possibilities of his database for the field of quantitative codicology, as it had been formulated by Ornato, since it was pos-

\footnotetext{
20 Beit-Arié 1977.
}

21 Sirat/Beit-Arié/Glatzer 1972-86.

22 This tool came to be known as SfarData, The Codicological Data-Base of The Hebrew Palaeography Project; see http://sfardata.nli.org.il/sfardatanew/home.aspx.

23 Thus, the book's subtitle: Tentative Typology of Technical Practices Employed in Hebrew Dated Medieval Manuscripts. 
sible to 'populate' the database with enough manuscripts to be able to carry out analyses of a statistical nature and arrive at conclusions based on quantifiable data, although this data was clearly limited to Hebrew codices that had been dated.

Beit-Arié acknowledges his debt to Ornato in Unveiled Faces of Medieval Hebrew Books, ${ }^{24}$ whose title is a clear homage - though in some respects an antithesis, according to Beit-Arié - of La face cachée. ${ }^{25}$ In spite of the methodological differences with Ornato that Beit-Arié points out, ${ }^{26}$ the essays that are included in Unveiled Faces leave no doubt as to their quantitative orientation, ${ }^{27}$ and this is a course that Beit-Arié has continued up to the present. ${ }^{28}$

\section{Comparative codicology}

Progress in the quantitative analysis of manuscript populations in both Latin and Hebrew areas and the development of codicology in other cultural fields such as Byzantine and Arabic studies soon prompted the question as to whether technological practices in manuscript production during the Middle Ages were shared by different language communities. This in turn led to the emergence of comparative codicology, a concept that takes its theoretical models and its methodological application from linguistics and comparative history. Comparativism arose as a methodology in linguistics during the $19^{\text {th }}$ century once the filiation of IndoEuropean and Semitic languages had been established and a method for compa-

24 Beit-Arié 2003.

25 Beit-Arié 2003, 11: 'My title's seemingly antithetic reference implies of course a certain methodological disagreement [with Ornato's methodology] and some differences in research procedure'. 26 Beit-Arié 2003, 13: ‘[...] theirs [Ornato’s and his school] can be described as an epistemological, speculative, conceptual, analytical, and fundamentally deductive approach. My methodology and practice, on the other hand, I consider to be positivistic, empirical, and inductive, perhaps even phenomenological and tangibility-oriented'. This declaration by Beit-Arié seems to contain a certain methodological reaction against the historical relativism occasioned by the application of the so-called 'linguistic turn' in the historical disciplines.

27 For example, 'Technical Evolution: Ruling Manuscripts', 'Copying Dynamics: Line Management', 'The Structural Transparency of Copied Texts'. The book's subtitle is revealing in this sense: 'The Evolution of Manuscript Production-Progression or Regression?', a question that can only be addressed on the basis of the assumptions and procedures of quantitative codicology.

28 See Beit-Arié 2014. http://web.nli.org.il/sites/NLI/English/collections/manuscripts/hebrewcodicology/Pages/default.aspx. 
rative-historical study of the attested languages in each family had been devised, with the objective of reconstructing a common ancestor, Proto-Indo-European in one case and Proto-Semitic in the other. ${ }^{29}$ But the more-direct examples of the development of comparative codicology are probably to be found in comparative history (particularly after the 1950s) and in the focus on non-European cultures driven by post-colonial studies.

Practically from the outset, comparative codicology pivots, on the one hand, around the development of the study of manuscript culture in 'Oriental' book traditions and, on the other, around the question as to whether it is possible to find universals in the material production of mediaeval manuscripts that would allow us to imagine the existence of a universal 'grammar' of the codex. This preoccupation has been formulated in linguistic terms, ${ }^{30}$ as is in relation with the development of structural codicology (see below).

Hebrew manuscript researchers realised the benefits of comparative study of mediaeval manuscripts very early on, particularly in the Hebrew manuscript culture, which lacked its own codicological tradition and shared manuscriptproduction techniques with the dominant culture in which Jewish communities lived, be it Latin-Christian, Byzantine-Orthodox or Arab-Islamic. ${ }^{31}$ Beit-Arié declared in 1977 that 'Medieval Hebrew handwritten books reflect both Oriental and Occidental, Christian and Islamic civilizations. In Hebrew manuscripts, Latin, Greek and Arabic paleography and Handschriftenkunde might find a tool for comparative intercultural study, ${ }^{32}$ an idea that he would assert again later, considering Hebrew manuscripts to be intercultural objects that are specially suitable for comparative analysis. ${ }^{33}$ Similarly, Colette Sirat, in her Hebrew Manuscripts of the Middle Ages, asserts that 'The history of Hebrew manuscripts is a part of a wider history, that of Arabic, Byzantine, and Latin manuscripts, and it can only fully be approached in the context of the general and comparative study of contemporary manuscripts'. ${ }^{34}$ The possibilities of comparative codicology were explored in a more systematic way from the 1990s at the Institut de recherche et d'histoire des textes (I.R.H.T.) in Paris. In 1998, as a result of a round

29 The use of this method was shown to be particularly fruitful with Romance languages, because unlike the Germanic and Slavic languages, both the source language (Latin) and the languages that were the result of its historical evolution were known, giving rise to Romance philology. See Tagliavini 1993, 47-51.

30 See Maniaci 2002, 25; Beit-Arié 1993a, 5.

31 Muzerelle 1991, 362; Sirat 1998, 132.

32 Beit-Arié 2014, 9.

33 Beit-Arié 1993a; Beit-Arié 1993b; in the same vein, more recently, van Boxel/Arndt 2010.

34 Sirat 2002, 16-17. 
table organised at the École normale supérieure in Paris, a volume of Recherches de codicologie comparée $e^{35}$ was published which included contributions by Beit-Arié and Sirat on Hebrew manuscripts, and a few years later a manual was published that was intended to serve as a guide for cataloguers of Latin, Greek, Arabic and Hebrew manuscripts. ${ }^{36}$ With a vast amount of territory still to be explored, the comparative codicological approach continues to give rise to ambitious projects ${ }^{37}$ and, together with quantitative codicology, constitutes one of the two most widespread methodological approaches to the material study of mediaeval manuscripts. ${ }^{38}$

\section{5 'Codicologie structurale' and the material description of manuscripts}

In the last two decades, some scholars applying ideas and concepts directly borrowed from structuralist linguistics have explored the idea of understanding a codex as a structure within a system of cultural transmission in which the codex's different components have a 'morphological' dimension - the identification of its constituent components - and a 'syntactic' dimension - the relationship between the different components, leading to the formulation of a 'codicologie structurale'. ${ }^{39}$ Like the archaeological approach, the structural study of codices is both synchronic and diachronic as it seeks not only to describe its constituent elements, but also to reconstruct the chronology of the object's production. For this reason, the identification of a codex's components, or morphology, also has a 'genetic' aspect, which relates to the origin of the components, and the study of

35 Hoffmann/Hunzinger 1998.

36 Géhin 2005. Participants in the Hebrew codicology section of this manual included Sonia Fellous, Jean-Pierre Rothschild and Monique Zerdoun in addition to Colette Sirat.

37 Noteworthy contributions to the field of comparative codicology include the aforementioned book by Agati 2009, and Bausi/Borbone/Sokolinski 2015; the latter is the product of a cooperative research network financed by the European Science Foundation between 2009 and 2014 and entitled 'COMSt: Comparative Oriental Manuscript Studies'. Research in comparative codicology is currently the principle activity at the Centre for the Study of Manuscript Cultures (CSMC) at the University of Hamburg, where various projects are underway focusing on manuscript cultures in Asia, Africa and Europe.

38 Described by J. Peter Gumbert as 'the two most striking modern developments [in codicology]', Agati 2009, 14.

39 On structural codicology, see Andrist/Canart/Maniaci 2013, which merges linguistic structuralism with the classic archaeological approach to the mediaeval codex. 
the relationship between the components - their 'syntax' - has a 'stratigraphic' aspect relating to the succession of the different forms that the codex has taken and under which it has circulated. ${ }^{40}$

The long-lasting impact of the archaeological turn and the more recent influence of structural codicology thus put the material description of manuscripts at the very heart of codicology. Johan Peter Gumbert, a pioneer in thinking about the material structure of mediaeval manuscripts, first formulated the concepts of 'unité codicologique/codicological unit' and 'césure/caesura', ${ }^{41}$ conceiving the former as 'une partie d'un livre résultant d'une activité qui peut être considérée comme unitaire sous le rapport du temps, du lieu et des circonstances' ${ }^{42}$ and the latter as 'une limite de cahier qui est en même temps une limite de texte, de main et/ou de quelque autre aspect codicologique' ${ }^{43}$ These two concepts were later developed by Gumbert and other specialists ${ }^{44}$ and help to establish a stratigraphy or syntax of the codex, i.e. to identify the codicological units of a manuscript (formed by one or more quires) - which correspond, in cases where there is more than one unit, to different stages of production - and the relationship among them.

The problem becomes more complex in cases where the manuscript has been through several stages of production, suffered losses or additions, or contains discrete codicological units - with different texts - of diverse origin and diverse natures. Gumbert remarked on the lack of adequate terminology and a suitable typology for describing the various structures that codices can have in their present form, in particular for the composite codex,${ }^{45}$ and he has proposed a system of classification based on the concepts of 'caesura' (boundary or discontinuity) and 'codicological unit' mentioned above and the newer concept of 'block' ${ }^{46}$ More recently, in a noteworthy effort at typological systematisation, Patrick Andrist, Paul Canart and Marilena Maniaci proposed a structural, stratigraphic and syntactical analysis of codices, including examples of the majority of possible material and textual anomalies that can be found in manuscripts,

40 Andrist/Canart/Maniaci 2013, 7.

41 In Gumbert 1989: 4-8; cited in Andrist/Canart/Maniaci 2013,14.

42 Gumbert 1989, 5.

43 Gumbert 1989, 6.

44 See Andrist/Canart/Maniaci 2013, 14-43.

45 'Non-homogeneous codex' for Gumbert 2004 and 'non unitario' codex for Maniaci 2004.

46 'A block [...] is different from a codicological unit in not having a complete, independent text or set of texts; and this implies that their order is not arbitrary, being dependent upon the text order', Gumbert 2004, 24. 
making it possible to describe them and provide better answers to the textual and historical questions posed by the codices themselves. ${ }^{47}$

These proposals aim for a structural, material understanding of codices in terms of their historical dimension and therefore also affect the understanding of the composition and transmission of texts. In his analysis of a $16^{\text {th }}$-century Bible manuscript in Arabic (Paris, Bibliothèque national de France, Ms. Arabe 1), Ronny Vollandt used the categories and terminology proposed by Gumbert to show that for codices that are thematically unitary and composed of multiple blocks, as is the case for the Bible he examined, structural analysis can reveal important facts about the process of its production, about the scribes and artisans who were involved in its production and about the selection of texts - in other words, about the final result as a book. ${ }^{48}$

\section{Sirat and the study of Hebrew manuscripts}

So far, it has been clearly stated that the methodological approach is a fundamental determinant for how a manuscript is studied and how its description is written and configured as a means to serve as a kind of 'intermediary' between the reader of a catalogue and the manuscript itself. ${ }^{49}$ Sirat, like Delaissé, Maniaci and others, understands codicology in the archaeological sense or 'stricto sensu', i.e. as the study of materials, forms and techniques used to produce a codex. ${ }^{50}$ She considers it to be one of three disciplines that deal with manuscript books, the other two being, in her opinion, the history of texts and palaeography, or the history of writing. ${ }^{51}$ For this reason, Sirat makes a careful distinction between a catalogue of manuscripts, which should contain not only a material description, but also a textual and historical outline of the codex in question, and a codicological catalogue, which should only deal with a codicological description 'stricto sensu.' She also cautions against the prominence that quantitative codicology has conferred on 'populations' of manuscripts - since they are not representative

47 Andrist/Canart/Maniaci 2013.

48 Vollandt 2012.

49 On the varieties and the history of manuscript descriptions, see the 2001 second edition of Armando Petrucci's book La descrizione del manoscritto: Storia, problemi, modelli, which is an essential resource. A brief history of cataloguing and an analysis of the types of Hebrew manuscript catalogues that exist can be found in del Barco 2014, 333-50.

50 Sirat 2002, 2.

51 Sirat 2002, 2. 
for certain types of manuscripts - and on the summary of purely material features while forgetting that manuscripts are, above all, bearers of a text:

\begin{abstract}
La codicologie [quantitative] explore les caractères matériels qui s’appliquent aux «populations» de manuscrits. [...] Ce courant de la codicologie pose cependant un problème de taille: dans notre domaine [les manuscrits hébreux], la méthode statistique s’applique mal au moyen âge; car, à défaut de pouvoir étudier la totalité d'un ensemble, cette méthode exige que l'échantillon examiné soit représentatif de toutes les parties de l'ensemble; or, ce qui nous a été conservé des manuscrits hébreux n'est sûrement pas représentatif de l'ensemble des manuscrits qui furent produits. [...] Un autre problème de la codicologie quantitative est qu'elle oublie quelquefois que le manuscrit est essentiellement un porteur de texte. [...] nous courrons le risque de donner une description trop minutieuse des caractères matériels du manuscrit et de confondre un catalogue de manuscrits avec un catalogue codicologique. La précision numérique rassure et donne l'impression que notre travail est «scientifique» de sorte que l'on aurait tendance à considérer que tous les caractères codicologiques doivent être relevés et que tous doivent l'être dans tous leurs détails. Or, au-delà d'un certain seuil, la minutie dans les détails n’ajoute pas de signification historique ; au contraire, elle retarde le travail du catalogueur et, en fin de compte, encombre le texte de la notice. ${ }^{52}$
\end{abstract}

Sirat's approach to the study of manuscripts, therefore, coincides with what other scholars have called codicology 'lato sensu', even though she prefers to reserve the term 'codicology' for the description of the material elements that make up a codex and serve as a medium for writing. Hers is closer to a neo-historicist approach to understanding the text and the mediaeval codex in which it is transmitted, ${ }^{53}$ which she considers to be a unique textual and historical object that must be studied in all the complexity of its forms and functions as well as in its cultural context. Therefore, the study of individual codices is essential, unlike in a quantitative approach, which seeks to identify general tendencies in large samples of manuscripts. For Sirat and her school, the history of the mediaeval manuscript book should be reconstructed from the sum of material, textual and historical peculiarities in each manuscript rather than from tendencies that are identified by conducting statistical analyses of selected material features within a sample of manuscripts..$^{54}$

For this reason, catalogues that follow the premises of quantitative codicology are clearly different from catalogues of manuscripts that follow a neo-his-

52 Sirat 2007a, 16-17.

53 This issue is dealt with in more detail in del Barco 2014, 344-346.

54 In Sirat's words: 'Because each of them is an individual, different from all others, every manuscript adds to our knowledge of the medieval world', Sirat 2007b, 27. 
toricist approach. In his description of what a codicological catalogue should be like according to the quantitative method, Albert Dérolez explains:

Sur quels aspects un catalogue pourra-t-il donc porter? Puisque le bout est de faire la comparaison entre de nombreux manuscrits, seulement sur les données qui se prêtent à une description rapide sans équivoque. ${ }^{55}$

By contrast, a neo-historicist catalogue accords equal attention to the material, textual and historical features of codices, highlighting the individuality of each manuscript under consideration, both with respect to its form (the material, textual and visual aspects) and its function (intellectually, culturally and historically). ${ }^{56}$

Notwithstanding this fundamental methodological distinction, and regardless of the connotation that each use of the term 'codicology' implies, a material description of manuscripts is essential in either type of catalogue since it is the basis for all other kinds of textual or historical analysis. In this sense, the progress made in the archaeological approach to the study of manuscripts and the suggestions offered by comparative and structural codicology mentioned above have all contributed new analytical tools that have greatly increased the strategies at our disposal for resolving the textual and historical difficulties that each manuscript presents.

\section{The comparative-structural approach: two case studies}

In the following, I shall present two examples of the comparative-structural approach: one that demonstrates the appropriateness of structural analysis for understanding the historical development of a book ${ }^{57}$ and another that demonstrates the relevance of studying the formal aspects of Hebrew manuscripts

55 Dérolez 1988, 5. This is precisely the kind of catalogue that we find in Dérolez 1984.

56 See del Barco 2011, VII-XVII, for the neo-historicist concept and method employed in the Hebrew manuscript catalogue at the Bibliothèque nationale de France, which has been published in a series of thematic volumes ever since 2008 as part of a joint project by the Bibliothèque nationale de France and the Institut de recherche et d'histoire des textes du CNRS.

57 See del Barco 2012 for this kind of approach to two miscellaneous manuscripts (one 'monomerous', the other 'homogenetic composite' in Gumbert's 2004 terminology), which are both kept at the Library of El Escorial. 
using a comparative approach following the guidelines provided by Beit-Arié and Sirat mentioned above. By providing these two examples, I would like to suggest the usefulness of studying the material aspects of Hebrew manuscripts using a combined, comparative-structural approach. Both examples come from manuscript descriptions that are to appear in a forthcoming catalogue. ${ }^{58}$ In the first manuscript, a historical approach requires a structural analysis first in order to discover the different stages in the material transformation of the manuscript and thereby address textual and historical questions. In the second one, what I want to show is that the study of the formal and functional aspects of Hebrew manuscripts cannot ignore comparative codicology or leave out a discussion of the dominant manuscript cultures in which Hebrew manuscripts were produced.

\subsection{Paris, BnF, Ms. Hébreu 35}

The first example is Paris, Bibliothèque nationale de France, Ms. Hébreu 35. This manuscript is an incomplete Bible containing two fragments of the Book of Numbers at the beginning, followed by the Psalms, Job and Proverbs, and finally Daniel, Ezra-Nehemiah and Chronicles. The colophon, copied at the end of EzraNehemiah (fol. 151r), reads:

אני יצחק ב"ר אביגדור כתבתי / זה העשרים וארבע לר' שלמה / בן הנדיב ר' משה שנת חמשת / אלפים וארבעים

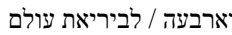

I, Yișhaq, son of R. Avigdor, have written this [Bible containing] the twenty-four [books] for R. Shelomo, son of the generous R. Moshe, in the year 5044 of the creation of the world [= $1284 \mathrm{CE}]$.

As previous descriptions of this manuscript have already noted, ${ }^{59}$ the scribe originally copied a complete Bible (all twenty-four books) in 1284, but in its present state, the manuscript lacks most of the Pentateuch, the Prophets and The Five Megillot ('scrolls').

Since the extant parts of the manuscript amount to 216 folios, it is conceivable that the entire Bible might easily have had about 600 folios. As we are

58 In a volume of the Catalogue of Hebrew Manuscripts at the Bibliothèque nationale de France, in the Brepols series Manuscrits en caracteres hébreux conservés dans les bibliothèques de France. 59 Zotenberg 1866, 4, no. 35; Sirat/Beit-Arié/Glatzer 1972-86, vol. I, no. 9; Garel 1991, 92, no. 61. 
dealing with an incomplete codex, the first step in its analysis should be to collate the quires in order to find boundaries or discontinuities ('caesuras' in Gumbert's terminology) in the material structure of the manuscript that would indicate the transformation it went through from its original form to its present state. The manuscript collation yields the following results:

- $\quad$ Quire 1: IV ${ }^{-4}$ (fols 1-4) [lacking the two external bifolia of the quire].

- $\quad$ Quire 2 to 19: IV (fols 5-12; 13-20; 21-28; 29-36; 37-44; 45-52; 53-60; 61-68; 69-76; 77-84; 85-92; 93-100; 101-108; 109-116; 117-124; 125-132; 133-140; 141-148).

- $\quad$ Quire 20: II (fols 149-152).

- $\quad$ Quire 21 to 28: IV (fols 153-160; 161-168; 169-176; 177-184; 185-192; 193-200; 201-208; 209-216).

Most of the quires are quaternions - quires consisting of four bifolia or eight folios - except for quire 1, which is incomplete, and quire 20, which is a binion - a quire consisting of two bifolia or four folios. Therefore, two main material caesuras exist, one involving quires 1 and 2 and the other involving quires 19, 20 and 21. In the first case, several folios are missing from quire 1 - the two external bifolia of the quire - resulting in a discontinuity between the end of quire 1 and the beginning of quire 2 . In the second case, we find that two blocks of quaternions, the first consisting of eighteen quires and the second of eight, are separated by a different type of quire - a binion. Such a discontinuity should warn us about a possible caesura in the structure of the manuscript.

The second step in analysing the syntax of the codex should be finding any textual discontinuities that might exist. These should be found in boundaries between textual units that coincide with material discontinuities. For this reason, it is necessary to check the first and last pages of each biblical book in order to identify any discontinuities and compare them with the quire structure. Textual boundaries checked against the quire structure are as shown in the following table: 
Table 1

\begin{tabular}{ll}
\hline Quire structure & Contents \\
\hline Quire 1 (fols 1-4) & Numbers 9:6 to 13:19 \\
Quire 2 (fols 5-12) & Numbers 14:40 to 21:23 \\
Quires 3 to 20 (fols 13-152) & Psalms (fols 13r-70r) \\
& Proverbs (fols 70r-89r) \\
& Job (fols 89r-111r) \\
& Daniel (fols 111r-126v) \\
& Ezra-Nehemiah (fols 126v-151r) \\
& Colophon (fol. 151r) \\
& Blank (fols 151v-152v) \\
& Chronicles (fols 153r-216r) \\
\hline
\end{tabular}

This table shows that there is a clear textual discontinuity between quires 2 and 3: quire 2 contains a fragment of Numbers, while quire 3 starts with the beginning of Psalms. The discontinuity between quires 1 and 2 , which was already indicated by the quire structure, is confirmed here by a textual discontinuity: two folios missing between quires 1 and 2 correspond to the lacuna of Numbers 13:20 to Numbers 14:39. Second, the end of Ezra-Nehemiah coincides with the material discontinuity between quires 20 and 21. Quire 20, the only binion in the entire manuscript, ends with a colophon followed by three blank pages, which is an unequivocal sign that this quire was the last one in the original codex. It is clear, then, that the end of the complete Bible when copied in $1284 \mathrm{CE}$ was at the end of Ezra-Nehemiah and not at the end of Chronicles, as it is now. We have to conclude that in the original project the Chronicles were not meant to be placed at the end of the manuscript, but at the beginning of the Ketuvim, as is customary in many other mediaeval Bibles.

The loss of the Prophets and the placement of the Chronicles at the end of the Bible occurred at an early stage, it seems. A Latin foliation of the manuscript, dating from the $14^{\text {th }}$ century, ${ }^{60}$ is still visible on many folios, giving an idea of the manuscript's structure at that time. Following this foliation, as shown in the table below, it is possible to deduce which parts of the Bible were still present in the $14^{\text {th }}$ century (the folios currently missing from the manuscript are in square brackets):

60 I would like to thank Patricia Stirnemann (I.R.H.T, C.N.R.S.), who kindly analysed and dated the Latin foliation and Latin glosses present in this manuscript. 
Table 2

\begin{tabular}{lll}
\hline Latin foliation & Folios & Contents \\
\hline [I-CXXXVI] & [136 fols missing] & [Genesis 1:1 to Numbers 9:5] \\
CXXXVII-CXL & Fols 1-4 & Numbers 9:6 to 13:19 \\
[CLXI-CXLII] & [2 fols missing] & [Numbers 13:20 to 14:39] \\
CXLIII-CL & Fols 5-12 & Numbers 14:40 to 21:23 \\
[CLI-CCXXXII] & [82 fols missing] & [End of Pentateuch + Megillot] \\
CCXXXIII- CCCCXXXVII & Fols 13-216 & Psalms, Proverbs, Job, Daniel, \\
& & Ezra-Nehemiah + Chronicles \\
\hline
\end{tabular}

According to the Latin foliation, the manuscript had 437 folios in the $14^{\text {th }}$ century, which is twice the number of extant folios today. The Pentateuch was certainly not faulty, and the 82 folios missing between folios 12 and 13 today included the end of the Pentateuch from Numbers 21:24 and most probably the Megillot as well. The Chronicles, according to this foliation, were already placed at the end of the manuscript, as they are today. This analysis allows us to interpret what happened between the production of the Bible in 1284 and the $14^{\text {th }}$ century, when the manuscript was already in Christian hands, as the Latin foliation attests.

To sum up, the analysis of the material and textual structure in this particular Bible suggests that the original order of the twenty-four books was the same as in other mediaeval Bibles: first the Pentateuch followed by the Prophets, and at the end the Ketuvim starting with the Chronicles, then the Megillot, and finally the rest of the books from Psalms to Ezra-Nehemiah as we find them in the present manuscript. At some point between 1284 and the $14^{\text {th }}$ century, the codex passed into Christian hands and suffered the first loss: the entire section of the Prophets. At the same time, the Chronicles were detached from the rest of the Ketuvim and were placed at the end of the manuscript, as the Latin foliation attests. In a later stage, and before the acquisition of the manuscript in the $16^{\text {th }}$ century by JacquesAuguste de Thou, Master of the Royal Library in Paris from $1593,{ }^{61}$ the codex suffered additional losses, including most of the Pentateuch and the Megillot. The changes in the textual structure of the manuscript are listed in the following table:

61 The Bible bears traces of its owners in the $16^{\text {th }}$ and $17^{\text {th }}$ centuries, before it entered the collections of the Royal Library in 1683: David Chambellan (d. in 1516), dean of Notre Dame de Paris; Jacques-Auguste de Thou (1553-1617), Master of the Royal Library; and finally, Jean-Baptiste Colbert (1619-1683), one of Louis XIV's principal ministers. 
Table 3

\begin{tabular}{lll}
\hline $\mathbf{1 2 8 4}$ & $1 \mathbf{4}^{\text {th }}$ century & $\mathbf{1 6}^{\text {th }}$ century - present \\
\hline Pentateuch & Pentateuch & $>$ Numbers (fragment) \\
Prophets & $>\varnothing$ & \\
Chronicles & $>$ [placed at the end $]$ & \\
Megillot & Megillot & $>\varnothing$ \\
Psalms, Proverbs, Job & Psalms, Proverbs, Job & Psalms, Proverbs, Job \\
Daniel & Daniel & Daniel \\
Ezra-Nehemiah & Ezra-Nehemiah & Ezra-Nehemiah \\
& + Chronicles & Chronicles \\
\hline
\end{tabular}

Further interpretation of palaeographic data may suggest a reason for such an early acquisition of the manuscript - the beginning of the $14^{\text {th }}$ century - by the Christians. Michel Garel has described the script of the biblical text as characteristically English, linking the change of owner at the end of the $13^{\text {th }}$ century with the expulsion of the Jews from England in $1290 .{ }^{62}$ However, Judith OlszowySchlanger, doubting the English character of the script, chose not to include this manuscript in her book on English manuscripts from the Middle Ages. ${ }^{63}$ I therefore suggest that the codex is probably French rather than English, and that the confiscation of the Bible by Christians should be explained in relation to the first expulsion of the Jews from France in 1306.

Recognising the original form of a codex and its structural transformations is crucial to the interpretation of textual and historical questions, as we have just seen in the previous example. It is also essential for defining a manuscript's function in the original context of its production. Special attention should be paid to certain formal features such as the selection of texts, variation in book order, arrangement of the page layout, the presence or absence of sections, subsections and titles, and the book's size. In the case of the Hebrew Bibles, these should also be taken into account in addition to other elements such as the presence or absence of the Masora, the selection of other texts such as the Targum, plus any mediaeval commentaries, grammatical works and liturgical texts that have been

62 'La graphie caracteristique de l'hébreu et l'écriture des gloses latines contemporaines de la copie déterminent sans conteste une origine insulaire [anglais] du codex', Garel 1991, 92, no. 61. 63 'L'écriture latine semble postérieure au XIIIe siècle, et il est difficile de trouver des arguments convaincants pour conclure que ce manuscrit ait été copié en Angleterre ou même qu'il s'y soit trouvé avant 1290’ Olszowy-Schlanger 2003, 43. Furthermore, according to Patricia Stirnemann, the Latin foliation and other annotations and Latin glosses are certainly French and from the mid- $14^{\text {th }}$ century. 
added over time. The arrangement of these texts on the page and their relation to the biblical one is also a telling factor reflecting reading practices, particular uses of the manuscript, and the patron's personal choices. ${ }^{64} \mathrm{~A}$ comparative study of typologies of Western Hebrew Bibles and Latin Bibles is also a necessary desideratum, as it can help us to understand book typology in its geographical, chronological and cultural context.

\subsection{Paris, BnF, Ms. Hébreu 33}

A model for such a comparative study of typologies could be provided by the second example, Paris, Bibliothèque nationale de France, Ms. Hébreu 33. This manuscript, copied in northern France in the $13^{\text {th }}$ century, is a very small Hebrew Bible containing, after the biblical books, a complete siddur according to the French rite. ${ }^{65}$ It measures only $100 \times 75 \mathrm{~mm}$, and the text is copied in irregular quires - most of them of fourteen or sixteen bifolia - on incredibly thin parchment. An extraordinary case among mediaeval Hebrew Bibles, the format of the 'pocket' Bible was nevertheless extremely popular among Latin Bibles of the $13^{\text {th }}$ century, produced mostly in Paris and in Bologna. ${ }^{66}$ The kind of parchment, the size of the volume and the palaeographic characteristics of this Bible all suggest an imitation of $13^{\text {th }}$-century Latin pocket Bibles. ${ }^{67}$ Moreover, the extensive use of abbreviations - a common scribal practice in Latin pocket Bibles - has its counterpart in this manuscript: the scribe abbreviated the text by writing only the first letter of each word in a section of Numbers, chapter 7, where most of every paragraph is a repetition of the same text. ${ }^{68}$ This is a scribal practice that I have not found anywhere else in Hebrew Bibles and it makes sense when the surrounding French and Latin manuscript culture is taken into account.

Furthermore, the copy of a siddur following the text of the Bible in the same manuscript also has to be explained in relation to the surrounding $13^{\text {th }}$-century manuscript culture. It is exceptional to find the text of the siddur in a Hebrew Bible,

64 David Stern has proposed the subcategorisation of mediaeval Hebrew Bibles into three types: the Masoretic Bible, the liturgical Bible and the study Bible, Stern 2012. This subcategorisation poses some typological problems in my opinion.

65 Manuscript only described previously in Zotenberg 1866, 4, no. 33.

66 See de Hamel 2001, 114-139, and Ruzzier 2013, 105-25.

67 The connection between this Hebrew Bible and Latin pocket Bibles from northern France was first suggested and contextualised by Sirat 1991, 312-13; and 1997, 246-47.

68 The section describes the offerings of the twelve tribes and belongs to the pericope Naso' (Num. 4:21-7:89). 
but this infrequent practice in Hebrew manuscripts has its parallel in a group of $13^{\text {th }}$-century Latin Bibles, mostly from France and England, where a Missal - or a selection of texts for the Mass - is copied together with the biblical text. ${ }^{69}$ Thus, it is most likely that this innovation in $13^{\text {th }}$-century Latin Bibles is behind the idea of producing a complete Hebrew Bible with a siddur in the same manuscript in $13^{\text {th }}$-century northern France.

\section{Conclusions}

The methodological proposals examined above and the examples that followed show comparative-structural analysis to be a powerful tool for historical and textual research on any manuscript that is not made up of a single 'undisturbed codicological unit, ${ }^{70}$ in other words the composite codex, given that such an approach helps to distinguish its codicological units and the relationship between them; the codex that presents multiple blocks to which various scribes or other artisans have contributed, although it only has one codicological unit; and any other manuscript that has undergone any modification that has changed its original structure. Comparative study of the historical and cultural context also provides the necessary parameters for understanding the codicological and textual practices of Hebrew manuscript production in the late Middle Ages. In my opinion, it is therefore useful for descriptions of catalogues of Hebrew manuscripts to include a structural, or syntactical, analysis of the codices in question as well as comparative and contextual perspectives on them within the dominant manuscript culture.

69 See Light 2013, 185-216.

70 Thus in Gumbert 2004, 33, in contrast to manuscripts composed of codicological units that have suffered accidents (losses, whether intentional or unintentional, and additions, whether textual or material). 


\section{References}

Agati, Maria Luisa (2009), Il libro manoscritto da Oriente a Occidente: Per una codicologia comparata (Studia Archaeologica), Rome: 'L'Erma' di Bretschneider.

Andrist, Patrick / Canart, Paul / Maniaci, Marilena (2013), La syntaxe du codex: Essai de codicologie structurale (Bibliologia: Elementa ad librorum studia pertinentia 34), Turnhout: Brepols.

Bausi, Alessandro / Borbone, Pier Giorgio / Sokolinski, Eugenia (eds) (2015), Comparative Oriental Manuscript Studies: An Introduction, [Hamburg]: COMSt.

Beit-Arié, Malachi (1977), Hebrew Codicology: Tentative Typology of Technical Practices Employed in Hebrew Dated Medieval Manuscripts, Paris: Institut de recherche et d'histoire des textes.

Beit-Arié, Malachi (1993a), 'Why Comparative Codicology?', in Gazette du livre médiéval 23: 1-5.

Beit-Arié, Malachi (1993b), Hebrew Manuscripts of East and West: Towards a Comparative Codicology (The Panizzi Lectures 1992), London: The British Library.

Beit-Arié, Malachi (2003), Unveiled Faces of Medieval Hebrew Books: The Evolution of Manuscript Production-Progression or Regression?, Jerusalem: Hebrew University, Magnes Press.

Beit-Arié, Malachi (2014), Hebrew Codicology: Historical and Comparative Typology of Hebrew Medieval Codices Based on the Documentation of the Extant Dated Manuscripts in [a] Quantitative Approach. Jerusalem: Israel Academy of Sciences and Humanities Press. Forthcoming, pre-publication internet version 0.4 [Hebrew]: http://web.nli.org.il/sites/ NLI/English/collections/manuscripts/hebrewcodicology/Pages/default.aspx.

Boxel, Piet van / Arndt, Sabine (eds) (2010), Crossing Borders: Hebrew Manuscripts as a Meeting-Place of Cultures, Oxford: Bodleian Library.

Bozzolo, Carla / Ornato, Ezio (1980), Pour une histoire du livre manuscrit au Moyen Âge: Trois essais de codicologie quantitative, Paris: Éditions du CNRS.

De Hamel, Christopher (2001), The Book: A History of the Bible. London, New York: Phaidon Press Limited.

Delaissé, Léon M. J. (1956), Le manuscrit autographe de Thomas à Kempis et l'«Imitation de Jésus-Christ», Paris: Erasme.

del Barco, Javier (2011), Bibliothèque nationale de France : Hébreu 1 à 32; Manuscrits de la Bible hébraïque (Manuscrits en caractères hébreux conservés dans les bibliothèques de France 4), Turnhout: Brepols.

del Barco, Javier (2012), 'Reconstructing the Early History of Two Kabbalistic Manuscripts from

El Escorial Library', in Manuscripta 56, no. 1: 1-27.

del Barco, Javier (2014), 'Catalogues of Hebrew Manuscripts in Historical Perspective', in Nicholas de Lange / Judith Olszowy-Schlanger (eds), Manuscrits hébreux et arabes: Mélanges en l'honneur de Colette Sirat (Bibliologia 38), Turnhout: Brepols, 333-350. Dérolez, Albert (1973), 'Codicologie ou archéologie du livre?', in Scriptorium 27: 47-49. Dérolez, Albert (1984), Codicologie des manuscrits en écriture humanistique sur parchemin Dérolez, Albert (1988), 'Catalogues codicologiques', in Gazette du livre médiéval 12: 4-6. (Bibliologia. Elementa ad librorum studia pertinentia 5, 6), Turnhout: Brepols.

Ebert, Friedrich Adolf (1825), Zur Handschriftenkunde, Leipzig: Steinacker und Hartknoch. Garel, Michel (1991), D’une main forte: Manuscrits hébreux des collections françaises. Paris: Seuil, Bibliothèque nationale. 
Géhin, Paul (2005), Lire le manuscrit médiéval: Observer et décrire, Collection U: Histoire, Paris: Armand Colin.

Gilissen, Léon (1977), Prolégomènes à la codicologie: Recherches sur la construction des cahiers et la mise en page des manuscrits médiévaux, Gand: Story-Scientia.

Gruys, Albert (1976), 'De la “Bücherhandschriftenkunde” d’Ebert à la “codicologie” de Masai', in Albert Gruys / Johan Peter Gumbert (eds), Codicologica. Vol. 1 (Litterae textuales), Leiden: Brill, 27-33.

Gruys, Albert / Gumbert, Johan Peter (eds) (1976-80), Codicologica, 5 vols (Litterae textuales), Leiden: Brill.

Gumbert, Johan Peter (1989), 'L'unité codicologique ou: À quoi bon les cahiers?', in Gazette du livre médiéval 14: 4-8.

Gumbert, Johan Peter (2004), 'Codicological Units: Towards a Terminology for the Stratigraphy of the Non-Homogeneous Codex', in Edoardo Crisci / Oronzo Pecere (eds), Il codice miscellaneo, tipologie e funzioni: Atti del convegno internazionale Cassino 14-17 maggio 2003 (= Segno e testo 2), Cassino: Università degli Studi di Cassino, 17-42.

Hoffmann, Philippe / Hunzinger, Christine (eds) (1998), Recherches de codicologie comparée: La composition du codex au Moyen Âge, en Orient et en Occident (Bibliologia), Paris: Presses de l'École Normale Supérieure.

Light, Laura (2013), 'The Thirteenth-Century Pandect and the Liturgy: Bibles with Missals', in Eyal Poleg / Laura Light (eds), Form and Function in the Late Medieval Bible, Leiden: Brill, 185-216.

Maniaci, Marilena (2002), Archeologia del manoscritto: Metodi, problemi, bibliografia recente. I libri di Viella, Rome: Viella.

Maniaci, Marilena (2004), 'Il codice greco "non unitario": Tipologie e terminologia', in Edoardo Crisci / Oronzo Pecere (eds), Il codice miscellaneo, tipologie e funzioni: Atti del convegno internazionale Cassino 14-17 maggio 2003 (= Segno e testo 2), Cassino: Università degli Studi di Cassino, 75-107.

Masai, François (1950), 'Paléographie et codicologie', in Scriptorium 4: 279-293.

Muzerelle, Denis (1991), 'Evolution et tendances actuelles de la recherche codicologique', in Historia, instituciones, documentos 18: 347-374.

Olszowy-Schlanger, Judith (2003), Les manuscrits hébreux dans l'Angleterre médievale: Étude historique et paléographique (Collection de la Revue des études juives 29), Paris, Dudley, MA: Peeters.

Olszowy-Schlanger, Judith (2012), 'Moritz Steinschneider and the Discipline of "Hebrew Manuscripts Study"', in Reimund Leicht / Gad Freudenthal (eds), Studies on Steinschneider: Moritz Steinschneider and the Emergence of the Science of Judaism in Nineteenth-Century Germany (Studies in Jewish History and Culture), Leiden, Boston: Brill, 249-262.

Ornato, Ezio / Bozzolo, Carla (1982), 'Pour une codicologie expérimentale', in Scrittura e civiltà 6: 263-302.

Ornato, Ezio (1997), La face cachée du livre médiéval: L'histoire du livre vue par Ezio Ornato, ses amis et ses collègues; Avec une préface d'Armando Petrucci (I libri di Viella 10), Rome: Viella.

Petrucci, Armando (2001), La descrizione del manoscritto: Storia, problemi, modelli. 2nd rev. edn., Rome: Carocci editore.

Poulle, Emmanuel (1978), Review of Codicologica. I, Théories et principes, by A. Gruys and J. P. Gumbert, in Bibliothèque d'humanisme et renaissance 41, no. 1: 149-50. 
Ruzzier, Chiara (2013), 'The Miniaturisation of Bible Manuscripts in the Thirteenth Century: A Comparative Study', in Eyal Poleg / Laura Light (eds), Form and Function in the Late Medieval Bible, 105-25 (Library of the Written Word 27, The Manuscript World 4), Leiden, Boston: Brill.

SfarData, The Codicological Data Base of The Hebrew Palaeography Project: http://sfardata.nli. org.il/sfardatanew/home.aspx.

Sirat, Colette (1991), 'Le livre hébreu en France au moyen âge', in Michael: On the History of the Jews in the Diaspora 12: 299-336.

Sirat, Colette (1997) 'Le livre hébreu: rencontre de la tradition juive et de l'esthétique française', in Gilbert Dahan / Gérard Nahon / Elie Nicolas (eds), Rashi et la culture juive en France du Nord au moyen âge (Collection de la Revue des études juives), Paris, Louvain: Peeters, 243-259.

Sirat, Colette (1998), 'Pour quelle raison trouve-t-on au Moyen Âge des quinions et des quaternions?', in Philippe Hoffmann / Christine Hunzinger (eds) (1998), Recherches de codicologie comparée: La composition du codex au Moyen Âge, en Orient et en Occident. 131-36, Bibliologia. Paris: Presses de l’École Normale Supérieure.

Sirat, Colette (2002), Hebrew Manuscripts of the Middle Ages, Cambridge: Cambridge University Press.

Sirat, Colette (2007a), 'Cataloguer les manuscrits hébreux du Moyen Âge', in Gazette du livre médiéval 50: 14-26.

Sirat, Colette (2007b), 'New Catalogues for Medieval Hebrew Manuscripts?', in Martin F. J. Baasten / Reinier Munk (eds), Studies in Hebrew Literature and Jewish Culture: Presented to Albert van Der Heide on the Occasion of His Sixty-Fifty Birthday, 21-30 (Amsterdam Studies in Jewish Thought 12), Dordrecht: Springer.

Sirat, Colette / Beit-Arié, Malachi / Glatzer, Mordekhai (1972-86), Manuscrits médiévaux en caractères hébraïques: Portant des indications de date jusqu'à 1540 - Otsar kitve-yad 'ivriyim mi-yeme-ha-benayim: Be-tsiyune ta'arikh 'ad shenat 5300.3 vols. Paris and Jerusalem: Centre National de la Recherche Scientifique, Ha-akademyah ha-le'umit ha-yisra'elit le-mada'im,.

Steinschneider, Moritz (1897), Vorlesungen über die Kunde hebräischer Handschriften, deren Sammlungen und Verzeichnisse. Leipzig: Otto Harrassowitz.

Stern, David. (2012), 'The Hebrew Bible in the Middle Ages: A Preliminary Typology', in Jewish Studies: An Internet Journal 11: 235-322.

Tagliavini, Carlo (1993), Orígenes de las lenguas neolatinas: Introducción a la filología romance. $2^{\mathrm{a}}$ reimp. Lengua y estudios literarios. México: Fondo de Cultura Económica.

Vollandt, Ronny (2012), 'The Production of Arabic Multi-Block Bibles: A Case Study of a CopticMuslim Workshop in Early Ottoman Cairo', in Comparative Oriental Manuscript Studies Newsletter 3: 31-36.

Zotenberg, Hermann (1866), Manuscrits orientaux : Catalogues des manuscrits hébreux et samaritains de la Bibliothèque Impériale. Paris: Imprimerie impériale. 
